\title{
Initial Development and Tolerance of Bell Pepper (Capsicum annuum) Cultivars under Salt Stress
}

\author{
Francisco V. da S. Sá ${ }^{1}$, Lauter S. Souto ${ }^{2}$, Emanoela P. de Paiva ${ }^{3}$, Erbia B. G. Araújo ${ }^{2}$, Fernanda A. de Oliveira ${ }^{2}$, \\ Evandro F. de Mesquita ${ }^{4}$, Miguel Ferreira Neto ${ }^{5} \&$ Jussara S. Dantas ${ }^{2}$ \\ ${ }^{1}$ Academic Unit of Agricultural Engineering, Federal University of Campina Grande, Campina Grande, PB, \\ Brazil \\ ${ }^{2}$ Academic Unit of Agricultural Science, Federal University of Campina Grande, Pombal, PB, Brazil \\ ${ }^{3}$ Department of Plant Production, Federal Rural University of Semi-Arid, Mossoró, RN, Brazil \\ ${ }^{4}$ Department of Agrarian and Exact Sciences, State University of Paraiba, Catolé do Rocha, PB, Brazil \\ ${ }^{5}$ Department of Environmental and Technological Sciences, Federal Rural University of Semi-Arid, Mossoró, \\ RN, Brazil \\ Correspondence: Francisco V. da S. Sá, Academic Unit of Agricultural Engineering, Federal University of \\ Campina Grande, Paraíba, Brazil. Tel: 55-083-99861-9267. E-mail: vanies_agronomia@hotmail.com
}

Received: August 19, 2017

doi:10.5539/jas.v9n11p181

\author{
Accepted: September 18, $2017 \quad$ Online Published: October 15, 2017 \\ URL: https://doi.org/10.5539/jas.v9n11p181
}

\begin{abstract}
The objective was to evaluate growth and tolerance of bell pepper cultivars under salt stress in the seedling stage. The experiment was carried out in protected environment (greenhouse) at the Center of Sciences and Agrifood Technology (CCTA) of the Federal University of Campina Grande (UFCG), located in the municipality of Pombal, Paraíba, from August to September 2014. Five bell pepper cultivars $\left(\mathrm{C}_{1}\right.$ - Dulce All Big; $\mathrm{C}_{2}-\mathrm{All} \mathrm{Big} ; \mathrm{C}_{3}-$ Italiano Amarelo Gigante; $\mathrm{C}_{4}$ - Rubi Gigante; $\mathrm{C}_{5}$ - Casca Dura Ikeda) were evaluated at five levels of irrigation water salinity $\left(0.6\right.$ (control); $1.2 ; 1.8,2.4$ and $3.0 \mathrm{dS} \mathrm{m}^{-1}$ ), arranged in $5 \times 5$ factorial scheme, in a completely randomized design, with four replicates. Bell pepper cultivars were grown on trays for 20 days after sowing, period in which they were evaluated for emergence, growth, phytomass accumulation and tolerance index. The increase in irrigation water salinity reduced bell pepper emergence, growth and dry matter accumulation, and the cultivars $\mathrm{C}_{2}-$ All Big and $\mathrm{C}_{4}$ - Rubi Gigante were the most tolerant to salinity in the initial growth stage. Tolerance to salinity occurred in the following order: $\mathrm{C}_{2}$ - All Big $>\mathrm{C}_{4}$ - Rubi Gigante $>\mathrm{C}_{1}-$ Dulce All Big $=\mathrm{C}_{5}$ - Casca Dura Ikeda $>\mathrm{C}_{3}$ - Italiano Amarelo Gigante.
\end{abstract}

Keywords: salinity, emergence, phytomass

\section{Introduction}

Bell pepper (Capsicum annuum L.) belongs to the Solanaceae family and is widely spread from the economic point of view, especially in Brazil, with an annually planted area of approximately 13 thousand hectares and production close to 290 thousand tons of fruits, which puts this vegetable among the five leguminous species with largest cultivated area in Brazil and worldwide (Moreira et al., 2008; Marouelli \& Silva, 2012). The Northeast region contributes with $31 \%$ of the national production of this crop, especially the states of Bahia, Ceará and Pernambuco (IBGE, 2012).

Bell pepper production in the region is still low because, as most vegetables, this crop is highly susceptible to water deficit, particularly during flowering and fruit formation and development, requiring the use of irrigation (Marouelli \& Silva, 2012). However, a large portion of Northeast Brazil is found in the semi-arid region, characterized by the occurrence of the phenomenon of periodic droughts (Medeiros et al., 2007; Silva et al., 2011; Sá et al., 2016). It is worth pointing out that irrigated agriculture depends on both quantity and quality of water, but the qualitative aspect has been little considered because, in the past, most water sources had better quality and were abundant (Silva et al., 2011).

In this context, lower-quality waters, such as domestic sewages, effluents from water treatment systems and industries, agricultural drainage waters and, particularly, brackish waters should be considered as alternative 
sources in bell pepper cultivation to solve the scarcity of water resources (Hespanhol, 2008). Savvas et al. (2007) also highlights that the availability of adequate water resources is a problem that occurs in agriculture at a global level, forcing many farmers to use water with relatively high saline concentration to irrigate crops. Hence, the use of saline waters in irrigation for plant production is a challenge that has been successfully overcome worldwide, due to the utilization of tolerant species and adoption of adequate practices of crop, soil and irrigation water managements (Munns \& Tester, 2008).

Nevertheless, the excess of salts may compromise root system development, growth and production of the crop. High saline concentrations in the soil increase the osmotic pressure of the medium, harming root development and the absorption of water and nutrients by plants (Sá et al., 2013; Mesquita et al., 2015). Evaluating the physiology of bell pepper plants under saline conditions, Sá et al. (2016) observed that the increase in salinity directly affects their photosynthetic efficiency, due to damages of stomatal and non-stomatal origins. Leonardo et al. (2007) demonstrated that there is an inverse correlation between soil EC (electrical conductivity) and mean fruit weight, because an increment of $1 \mathrm{dS} \mathrm{m}^{-1}$ in the soil contributes, on average, to a decrement of $15 \%$ in the mean weight of each bell pepper fruit.

However, studies on C. annuиm L. cultivars regarding its tolerance to salinity are either scarce or nonexistent, thus the present study will contribute to the expansion of the crop in semi-arid areas with qualitative scarcity of water resources. Hence, this study aimed to evaluate growth and tolerance of bell pepper cultivars under salt stress in the seedling stage.

\section{Material and Methods}

The experiment was carried out from August to September 2014 in protected environment (greenhouse) at the Center of Sciences and Agrifood Technology (CCTA) of the Federal University of Campina Grande (UFCG), located in the municipality of Pombal, Paraíba, at geographic coordinates $6^{\circ} 47^{\prime} 20^{\prime \prime} \mathrm{S}$ and $37^{\circ} 48^{\prime} 01^{\prime \prime} \mathrm{W}$, at altitude of $194 \mathrm{~m}$.

Five bell pepper cultivars $\left(\mathrm{C}_{1}\right.$ - Dulce All Big; $\mathrm{C}_{2}$ - All Big; $\mathrm{C}_{3}$ - Italiano Amarelo Gigante; $\mathrm{C}_{4}$ - Rubi Gigante; $\mathrm{C}_{5}$ - Casca Dura Ikeda) were evaluated at five levels of irrigation water salinity (S1 - 0.6 (control); S2 - 1.2; S3 - 1.8; $\mathrm{S} 4-2.4$ and $\mathrm{S} 5-3.0 \mathrm{dS} \mathrm{m}^{-1}$ ), of which two are below the crop salinity threshold of $1.5 \mathrm{dS} \mathrm{m}^{-1}$ (Maas \& Hoffman, 1977) and three above it, in order to identify genotypes with higher tolerance or sensitivity to water salinity. Treatments were arranged in $5 \times 5$ factorial scheme, in a completely randomized design, with four replicates.

Bell pepper plants were cultivated on trays of 30 cells with capacity for $0.1 \mathrm{dm}^{3}$ of substrate, until 20 days after sowing (DAS). The substrate for seedling production was composed of soil and commercial substrate, mixed at 1:1 proportion, and its chemical characterization is presented in Table 1 (Santos et al., 2013). For sowing, 30 cells were allocated to each treatment, so that each cell received one seed, totaling 30 seeds per treatment. After emergence, seedlings were thinned to leave only the most vigorous plant per cell. The seeds of both cultivars were purchased in a commercial establishment, with $99 \%$ purity and $95 \%$ germination.

Table 1. Chemical characteristics of the components of the substrate used for bell pepper cultivation

\begin{tabular}{|c|c|c|c|c|c|c|c|c|c|c|c|c|}
\hline & $\mathrm{EC}$ & $\mathrm{pH}$ & $\mathrm{P}$ & $\mathrm{K}^{+}$ & $\mathrm{Ca}^{+2}$ & $\mathrm{Mg}^{+2}$ & $\mathrm{Na}^{+}$ & $\mathrm{Al}^{3+}$ & $\mathrm{H}^{+}+\mathrm{Al}^{3+}$ & SB & $\mathrm{T}$ & $\mathrm{OM}$ \\
\hline & $\mathrm{dS} \mathrm{m}^{-1}$ & $\mathrm{H}_{2} \mathrm{O}$ & $\mathrm{mg} \mathrm{dm} \mathrm{m}^{-3}$ & ------ & -------. & ------. & $\mathrm{cmc}$ & $\mathrm{dm}^{-3}$ & & --- & ------- & $\mathrm{g} \mathrm{kg}^{-3}$ \\
\hline A & 0.09 & 8.07 & 3.00 & 0.32 & 6.40 & 3.20 & 0.18 & 0.00 & 0.00 & 10.49 & 10.49 & 16.0 \\
\hline B & 1.65 & 5.75 & 86.00 & 1.67 & 11.60 & 28.50 & 17.84 & 0.00 & 11.88 & 59.61 & 71.49 & 570.0 \\
\hline
\end{tabular}

Note. $\mathrm{SB}=$ sum of bases; $\mathrm{EC}=$ electrical conductivity; $\mathrm{T}=$ total cation exchange capacity; $\mathrm{OM}=$ organic matter; $\mathrm{A}=$ Soil; $\mathrm{B}=$ commercial substrate.

Irrigations were daily applied to maintain soil moisture close to the maximum retention capacity, based on the drainage lysimetry method; applied volume plus a leaching fraction $(L F)$ of $20 \%$. The volume applied per container $\left(V_{a}\right)$ was obtained by the difference between the previous volume $\left(V_{\text {prev }}\right)$ minus the mean drainage (d), divided by the number of containers $(n)$, as shown in Equation 1:

$$
V_{a}=\frac{V_{\text {prev }}-D}{n(1-L F)}
$$

Irrigation water with various salinity levels was prepared considering the relationship between $\mathrm{EC}_{\mathrm{w}}$ and concentration of salts (10.meq $\mathrm{L}^{-1}=1 \mathrm{dSm}^{-1}$ of $\mathrm{EC}_{\mathrm{w}}$ ) according to Rhoades et al. (1992), valid for $\mathrm{EC}_{\mathrm{w}}$ interval 
from 0.1 to $5.0 \mathrm{dS} \mathrm{m}^{-1}$, which encompasses the studied levels. Public-supply water available in the area $\left(\mathrm{EC}_{\mathrm{w}}=\right.$ $\left.0.3 \mathrm{dS} \mathrm{m}^{-1}\right)$ was used, mixed with salts $(\mathrm{NaCl})$ as necessary (Table 2).

Table 2. Chemical analysis of the public-supply water used to prepare the solutions

\begin{tabular}{|c|c|c|c|c|c|c|c|c|c|c|c|}
\hline \multirow{3}{*}{ Water } & $\mathrm{EC}_{\mathrm{a}}$ & $\mathrm{pH}$ & $\mathrm{K}$ & $\mathrm{Ca}$ & $\mathrm{Mg}$ & $\mathrm{Na}$ & $\mathrm{SO}_{4}^{-2}$ & $\mathrm{CO}_{3}{ }^{-2}$ & $\mathrm{HCO}_{3}^{-}$ & $\mathrm{Cl}^{-}$ & $\mathrm{SAR}^{1}$ \\
\hline & $\mathrm{dSm}^{-}$ & & & --- & --- & $(\mathrm{mn}$ & $\left.\mathrm{l}_{\mathrm{c}} \mathrm{L}^{-1}\right)-$ & -------- & - & \multicolumn{2}{|c|}{$--\left(\mathrm{mmol}_{\mathrm{c}} \mathrm{L}^{-1}\right)^{0.5}$} \\
\hline & 0.3 & 7.0 & 0.3 & 0.2 & 0.6 & 1.4 & 0.2 & 0.0 & 0.8 & 1.3 & 2.21 \\
\hline
\end{tabular}

Note. $\mathrm{EC}=$ electrical conductivity; $\mathrm{SAR}=$ Sodium adsorption ratio.

After prepared, the saline solutions were stored in 30-L plastic containers, one for each $\mathrm{EC}_{\mathrm{w}}$ level, properly protected to avoid evaporation, entry of rainwater and contamination by material that could compromise quality. To prepare the solutions with the respective EC levels, salts $(\mathrm{NaCl})$ were weighed according to the treatment and water was added until reaching the desired EC level. EC values were verified using a portable conductivity meter, with conductivity adjusted to temperature of $25^{\circ} \mathrm{C}$.

During the experiment, bell pepper emergence was monitored by counting the number of emerged seedlings, i.e., with cotyledons above the soil level, daily performed without discarding the plants, thus obtaining a cumulative value. Hence, the number of emerged plants referring to each count was obtained by subtracting the reading of the previous day from the current reading. Thus, the number of emerged seedlings relative to each reading, obtained in greenhouse, was used to calculate the mean time of emergence (MTE) through the formula described by Araújo et al. (2016):

$$
\mathrm{MTE}=\frac{\left(\mathrm{N}_{1} \mathrm{G}_{1}\right)+\left(\mathrm{N}_{2} \mathrm{G}_{2}\right)+\ldots+\left(\mathrm{N}_{\mathrm{n}} \mathrm{G}_{\mathrm{n}}\right)}{\mathrm{G}_{1}+\mathrm{G}_{2}+\ldots+\mathrm{G}_{\mathrm{n}}}
$$

Where, $\mathrm{MTE}=$ mean time of emergence (dias); $\mathrm{G}=$ number of emerged seedlings observed in each count; $\mathrm{N}=$ number of days from sowing to each count.

After emergence stabilization, emergence percentage (EP) (\%) was determined by the relationship between the number of emerged seedlings and number of seeds sown.

To monitor the morphological aspect of the crop, plant growth was evaluated at 20 DAS: number of leaves (NL), based on the count of mature leaves; plant height $(\mathrm{PH})$, measured with a ruler; and stem diameter (SD), measured using a caliper. After growth analysis, plants were collected, separated into shoots and roots and dried in a forced-air oven at $65{ }^{\circ} \mathrm{C}$, until constant weight. The dried material was then weighed on analytical scale to determine shoot dry matter (SDM) (g) and root dry matter (RDM) (g). These data were used to determine total dry matter (TDM) $(\mathrm{g})$, through the sum of SDM and RDM, and root/shoot ratio (R/S), through the division RDM/SDM.

Total dry matter production data were used to calculate the percentages partitioned among vegetative organs and the salinity tolerance index, by comparing the data of the saline treatments with those of the control $\left(\mathrm{EC}_{\mathrm{w}}=0.6\right.$ $\mathrm{dS} \cdot \mathrm{m}^{-1}$ ), according to the methodology of Fageria et al. (2010), based on four levels of classification: T (tolerant; 0-20\%), MT (moderately tolerant; 21-40\%), MS (moderately sensitive; 41-60\%) and S (Sensitive; $>60 \%$ ), as demonstrated in Equation 3:

$$
S T I(\%)=\frac{\text { TDM production in the saline treatment }}{\text { TDM production in the control treatment }} \times 100
$$

The calculations of these indices used the total dry matter production of the cultivars as the main parameter to determine their tolerance to salt stress.

The obtained data were subjected to analysis of variance by $\mathrm{F}$ test and, in case of significance, regression analyses were applied for the factor irrigation water salinity levels, while Tukey test was applied for the factor cultivars, both at 0.05 probability level, using the statistical software SISVAR $®$ (Ferreira, 2011). The data were subjected to standardization to show null mean value $(\overline{\mathrm{X}}=0)$ and variance equal to one $(\sigma=1)$. Subsequently, cluster analysis was performed through the hierarchical method, Ward's minimum variance, using the Euclidean Distance as the measure of dissimilarity (Hair et al., 2009). 


\section{Results and Discussion}

There was significant influence $(\mathrm{p}<0.05)$ of the interaction between irrigation water salinity levels and bell pepper cultivars on the variables emergence percentage, mean time of emergence, plant height, stem diameter, number of leaves, total dry matter and salinity tolerance index (Figures 1,2 and 3).

The increase in irrigation water salinity linearly reduced emergence percentage (EP) in the bell pepper cultivars, causing reductions of $12.11,17.59,7.41,14.82$ and $15.74 \%$ per unit increase in salinity, for the cultivars $\mathrm{C}_{1}$ Dulce All Big, $\mathrm{C}_{2}-\mathrm{All} \mathrm{Big}, \mathrm{C}_{3}$ - Italiano Amarelo Gigante, $\mathrm{C}_{4}-$ Rubi Gigante and $\mathrm{C}_{5}-$ Casca Dura Ikeda, respectively (Figure 1A).

Among the cultivars, $\mathrm{C}_{3}$ - Italiano Amarelo Gigante showed the highest EP values at all salinity levels, denoting lower sensitivity of this cultivar to salt stress in the stage of germination and emergence, compared with the others (Figure 1A). The cultivar $\mathrm{C}_{2}-\mathrm{All}$ Big showed the greatest reduction due to the increase in irrigation water salinity, equal to $50 \%$ between the highest $\left(3.0 \mathrm{dS} \mathrm{m}^{-1}\right)$ and lowest $\left(0.6 \mathrm{dS} \mathrm{m}^{-1}\right)$ levels of salinity (Figure 1B). Lopes et al. (2008) explain that the presence of salts interferes with soil water potential, reducing the gradient of potential between soil and seed surface, restricting water absorption by the seed and reducing germination rates, which justifies such decrease in the emergence potential of bell pepper seeds in all cultivars evaluated in the present study, as shown in Figure 1.

Increment in irrigation water salinity linearly increased the mean time of germination (MTE) of the bell pepper cultivars. This variable increased by $0.71,1.00,0.84,1.55$ and 1.22 days for the cultivars $\mathrm{C}_{1}$ - Dulce All Big, $\mathrm{C}_{2}$ All Big, $\mathrm{C}_{3}$ - Italiano Amarelo Gigante, $\mathrm{C}_{4}$ - Rubi Gigante and $\mathrm{C}_{5}$ - Casca Dura Ikeda, respectively, for every 1 $\mathrm{dS} \mathrm{m} \mathrm{m}^{-1}$ increase in irrigation water salinity (Figure 1B).

MTE was most affected by the increase in salinity in the cultivars $\mathrm{C}_{4}$ - Rubi Gigante and $\mathrm{C}_{5}$ - Casca Dura Ikeda, which showed increments of 33.84 and $37.25 \%$ between the highest $\left(3.0 \mathrm{dS} \mathrm{m}^{-1}\right)$ and lowest $\left(0.6 \mathrm{dS} \mathrm{m}^{-1}\right)$ levels of salinity (Figure 1B). The elevation of osmotic pressure caused by the excess of soluble salts in the soil solution may reach a level at which plants will not have enough suction power to overcome the osmotic potential and, therefore, they will not absorb water and, consequently, nutrients, due to the water stress condition (Dias \& Blanco, 2010). Such reduction of osmotic potential retards emergence and may even inhibit plant germination. Similar results were found in eggplant cultivars (Oliveira et al., 2016) and melon cultivars (Araújo et al., 2016) subjected to different levels of irrigation water salinity. The authors observed that the increase in water salinity and, consequently, in the accumulation of salts in the soil retards seed germination in these species and even inhibits it at the highest saline levels.

A

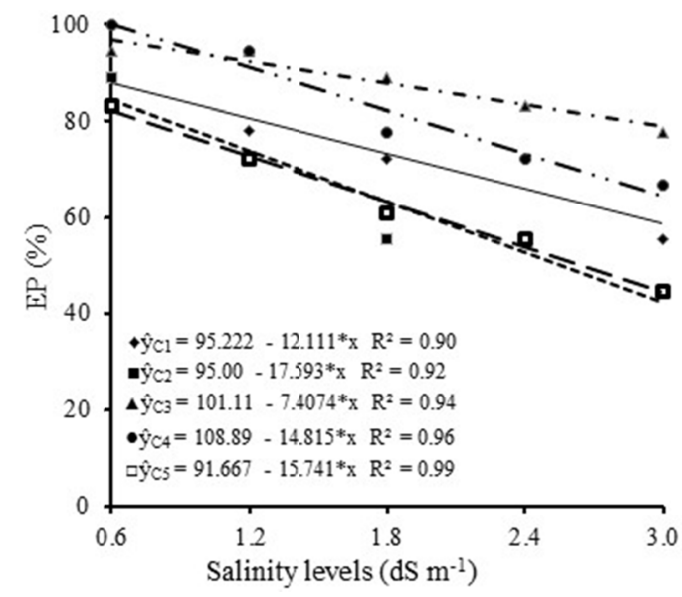

B

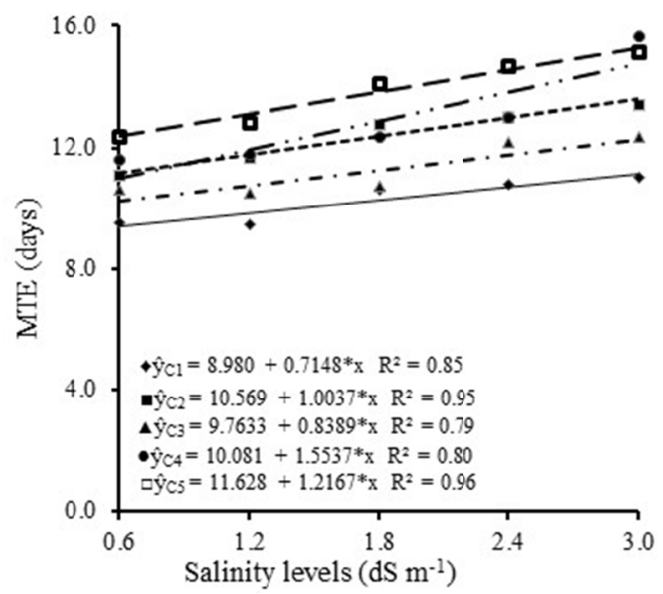

Figure 1. Emergence percentage (EP) and mean time of emergence (MTE) of bell pepper cultivars under salt stress in the initial growth stage

Note. ${ }^{\mathrm{NS}}$ and $*=$ not significant $(\mathrm{p}>0.05)$ and significant at 0.05 probability level $(\mathrm{p}<0.05) ; \mathrm{C}_{1}-$ Dulce All Big. $\mathrm{C}_{2}$ - All Big. $\mathrm{C}_{3}$ - Italiano Amarelo Gigante. $\mathrm{C}_{4}$ - Rubi Gigante and $\mathrm{C}_{5}$ - Casca Dura Ikeda. 
Regarding plant height $(\mathrm{PH})$, the increase in irrigation water salinity led to reduction in the growth of all bell pepper cultivars. The cultivars $\mathrm{C}_{1}$ - Dulce All Big, $\mathrm{C}_{2}$ - All Big, $\mathrm{C}_{3}$ - Italiano Amarelo Gigante, $\mathrm{C}_{4}$ - Rubi Gigante and $\mathrm{C}_{5}$ - Casca Dura Ikeda showed linear reductions on the order of $0.64,0.43,0.68,0.32$ and $0.72 \mathrm{~cm}$ in $\mathrm{PH}$, respectively, for every $1 \mathrm{dS} \mathrm{m}^{-1}$ increase in irrigation water salinity (Figure 2A). Andrade et al. (2016), in an experiment with the cultivar All Big, observed that plant height increased with the increment in the salinity levels up to the optimal limit of $2.2 \mathrm{dS} \mathrm{m}^{-1}$, and linearly decreased from this point on, which differs from the results presented in the graphs of Figure 3, in which the height of seedlings in the initial growth stage decreased with the increment of EC. Values found by Lima et al. (2015), who evaluated eggplant height, also indicate a linear reduction caused by salinity, leading to loss of $4.35 \mathrm{~cm}$ per unit increase in salinity and resulting in a total reduction of $27.5 \%$ in plants irrigated using water with highest salinity level $\left(6.0 \mathrm{dS} \mathrm{m}^{-1}\right)$.

A

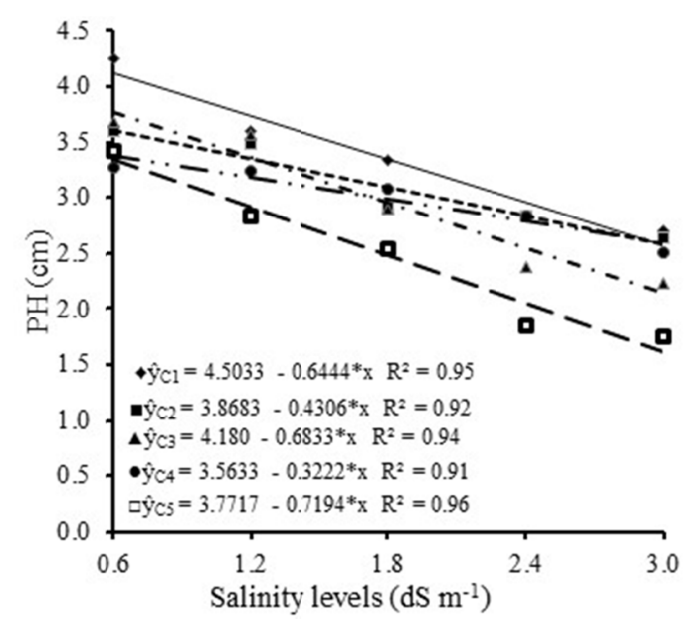

$\mathrm{C}$

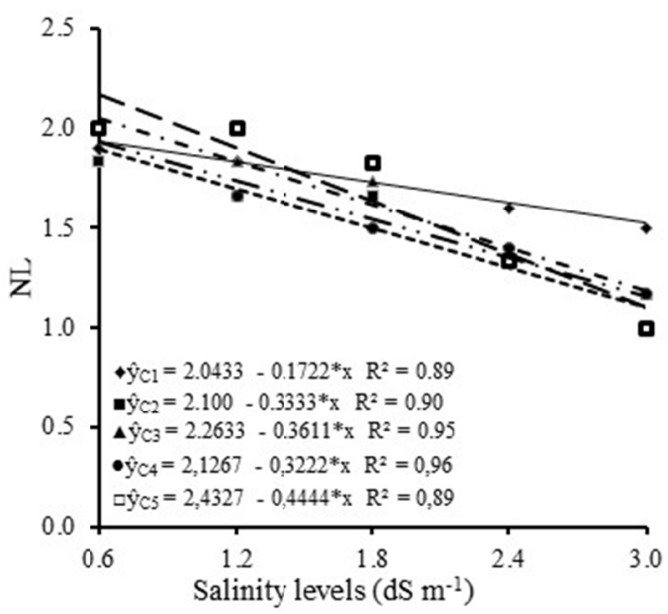

B

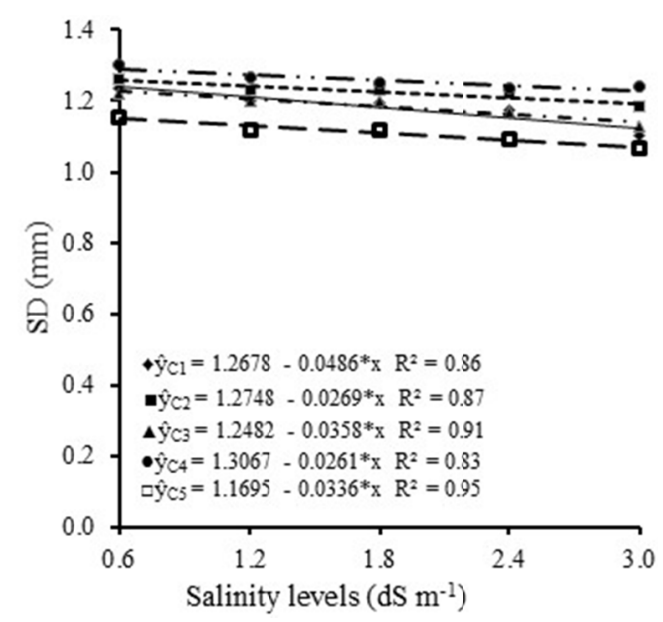

$\mathrm{D}$

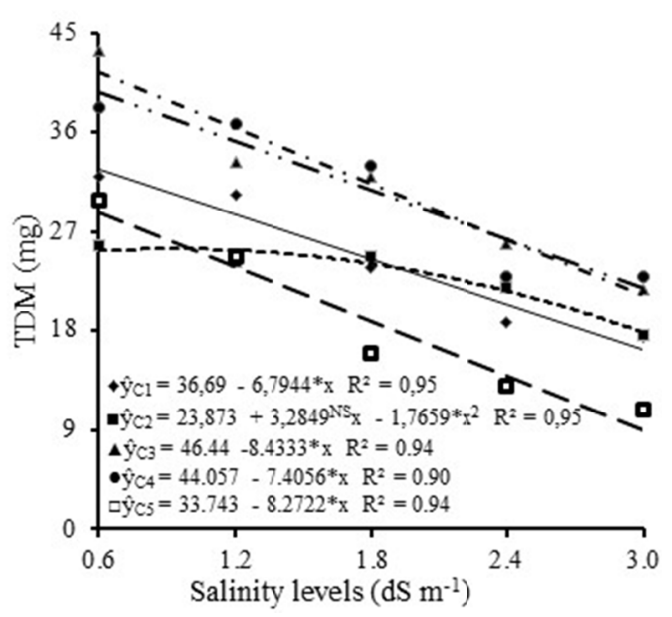

Figure 2. Plant height. PH (A). stem diameter. SD (B). number of leaves. NL (C) and total dry matter. TDM (D) of bell pepper cultivars under salt stress in the initial growth stage

Note. ${ }^{\text {NS }}$ and $*=$ not significant $(\mathrm{p}>0.05)$ and significant at 0.05 probability level $(\mathrm{p}<0.05) ; \mathrm{C}_{1}-$ Dulce All Big. $\mathrm{C}_{2}$ - All Big. $\mathrm{C}_{3}$ - Italiano Amarelo Gigante. $\mathrm{C}_{4}$ - Rubi Gigante and $\mathrm{C}_{5}$ - Casca Dura Ikeda. 


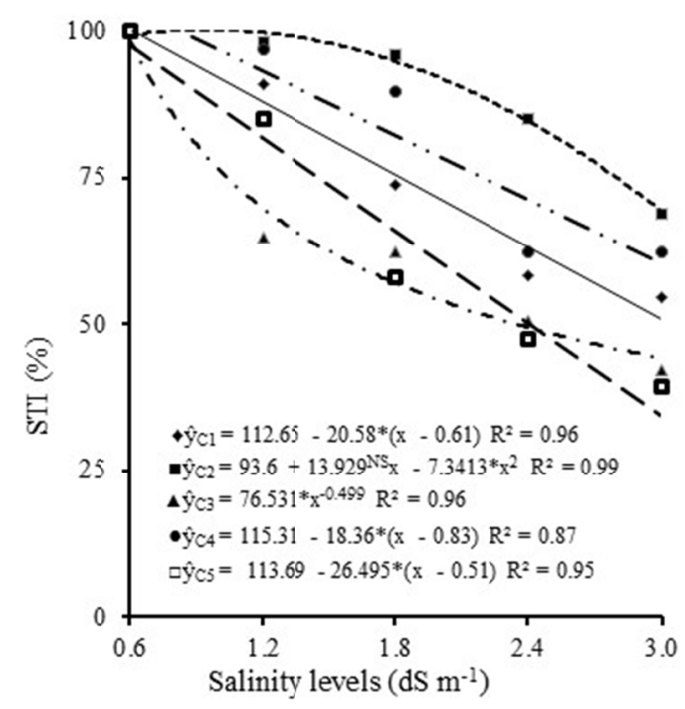

Figure 3. Salinity tolerance index (STI) of bell pepper cultivars under salt stress in the initial growth stage Note. ${ }^{\mathrm{NS}}$ and $*=$ not significant $(\mathrm{p}>0.05)$ and significant at 0.05 probability level $(\mathrm{p}<0.05) ; \mathrm{C}_{1}-$ Dulce All Big. $\mathrm{C}_{2}$ - All Big. $\mathrm{C}_{3}$ - Italiano Amarelo Gigante. $\mathrm{C}_{4}$ - Rubi Gigante and $\mathrm{C}_{5}$ - Casca Dura Ikeda.

For stem diameter (SD), the increase in irrigation water salinity caused decreases in the growth of all bell pepper cultivars, with linear reductions on the order of $0.049,0.027,0.036,0.026$ and $0.034 \mathrm{~mm}$ for the cultivars $\mathrm{C}_{1}$ Dulce All Big, $\mathrm{C}_{2}-$ All Big, $\mathrm{C}_{3}$ - Italiano Amarelo Gigante, $\mathrm{C}_{4}$ - Rubi Gigante and $\mathrm{C}_{5}$ - Casca Dura Ikeda, respectively, for every $1 \mathrm{dS} \mathrm{m}^{-1}$ increase in irrigation water salinity (Figure 2B). Silva et al. (2013) suggest that solutes dissolved in the root zone generate a lower osmotic potential, which reduces the total potential of the soil; therefore, plant development is compromised. Reduction of stem diameter due to the increase in irrigation water salinity was also found in the cultivar All Big by Sá et al. (2016), as well as in other vegetables, such as eggplant (Oliveira et al., 2016) and cucumber (Albuquerque et al., 2016). The authors attribute these reductions to the increase in the osmotic potential and excessive accumulation of $\mathrm{NaCl}$ salts, which cause toxicity to plants when absorbed in excess, leading to damages of physiological nature, which restrict plant growth.

The number of leaves in the bell pepper cultivars linearly decreased due to the increment in irrigation water salinity, with reductions of 0.17, 0.33, 0.36, 0.32 and 0.44 leaves in the cultivars $\mathrm{C}_{1}$ - Dulce All Big, $\mathrm{C}_{2}$ - All Big, $\mathrm{C}_{3}$ - Italiano Amarelo Gigante, $\mathrm{C}_{4}$ - Rubi Gigante and $\mathrm{C}_{5}$ - Casca Dura Ikeda, respectively, for every $1 \mathrm{dS} \mathrm{m}^{-1}$ increase in irrigation water salinity (Figure $2 \mathrm{C}$ ). The results found in the present study did not differ from those reported by Lima et al. (2015), who observed that number of leaves and leaf area in eggplant were negatively affected by irrigation water salinity and showed a linear reduction. Nascimento et al. (2015), also evaluating the bell pepper crop, observed linear reduction in the number of leaves with the increment in the saline levels as well.

According to Rubio et al. (2004), the saline ions prevailing in salt-affected soils (particularly, $\mathrm{Na}^{+}$and $\mathrm{Cl}^{-}$) can affect the absorption of nutrients directly, through competitive interactions, or indirectly, by increasing the permeability of cell membranes, especially plasmalemma. The harmful effects on the leaves are more intense for the photosynthetic process, since the increase of salts reduces the production, accumulation and distribution of photoassimilates that are vital to the plants (Taiz \& Zeiger, 2013).

Growth reductions in the bell pepper cultivars had an impact on their dry matter accumulation, and the total dry matter accumulation was directly reduced by the increment in irrigation water salinity. There were reductions of $6.79,3.28,8.43,7.41$ and $8.27 \mathrm{mg}$ in the TDM of the cultivars $\mathrm{C}_{1}$ - Dulce All Big, $\mathrm{C}_{2}-$ All Big, $\mathrm{C}_{3}$ - Italiano Amarelo Gigante, $\mathrm{C}_{4}$ - Rubi Gigante and $\mathrm{C}_{5}$ - Casca Dura Ikeda, respectively, for every $1 \mathrm{dS} \mathrm{m}^{-1}$ increase in irrigation water salinity (Figure 2D). Successive irrigations with saline waters increase the concentrations of soluble salts in the soil, especially when the waters are rich in $\mathrm{NaCl}$ salts, and these high concentrations cause plants to absorb these ions and, after accumulating in the plants, these ions trigger a series of physiological, hormonal and nutritional disorders caused by the ionic imbalance within plant cells (Munns \& Tester, 2008; Taiz \& Zeiger, 2013). Araújo et al. (2016) observed that, regardless of the studied cultivars, the increase in irrigation water salinity in the melon crop caused negative effects on shoot (SDM), root (RDM) and total (TDM) dry 
matter accumulation, with losses of $12.2 \%, 17.6 \%$ and $21.8 \%$, not differing from the crop evaluated in the present study regarding the reduction in weight of the cultivars with the increment in irrigation water salinity.

According to the salinity tolerance index, the cultivars $\mathrm{C}_{2}$ - All Big and $\mathrm{C}_{4}$ - Rubi Gigante are more tolerant to salinity, showing moderate tolerance up to the salinity levels of 3.0 and $2.7 \mathrm{dS} \mathrm{m}^{-1}$, respectively, based on the classification of Fageria et al. (2010), which has four levels: T (tolerant; 0-20\%), MT (moderately tolerant; 21-40\%), MS (moderately sensitive; 41-60\%) and S (Sensitive; > 60\%). According to this classification, the cultivars $\mathrm{C}_{1}$ - Dulce All Big, $\mathrm{C}_{3}$ - Italiano Amarelo Gigante and $\mathrm{C}_{5}$ - Casca Dura Ikeda are moderately sensitive from the levels of 2.1, 1.4 and 2.1 $\mathrm{dS} \mathrm{m}^{-1}$ on, respectively (Figure 3).

According to the cluster analysis, based on the Euclidean Distance as the measure of dissimilarity, five groups were formed by the combinations between salinity levels (S) and bell pepper cultivars (C) (Figure 4). The first (I) and second (II) clusters can be characterized by low salinity and high performance of germination and allocation of shoot and root phytomass. In these two groups, the cultivars $\mathrm{C}_{2}$ and $\mathrm{C}_{4}$ stood out for maintaining high performance, respectively at high salinity levels $\left(1.8,2.4\right.$ and $\left.3.0 \mathrm{dS} \mathrm{m}^{-1}\right)$ and up to the level of $1.8 \mathrm{dS} \mathrm{m}^{-1}$, denoting tolerance of these genotypes to salinity. The third (III), fourth (IV) and fifth (V) clusters are characterized by high salinity and low performance of germination and dry matter accumulation in shoots and roots. The cultivar $\mathrm{C}_{3}$ had the worst performance, standing out as the most sensitive, along with the cultivars $\mathrm{C}_{1}$ and $\mathrm{C}_{5}$, which confirms the hierarchy of tolerance observed in STI, with expressive reduction of performance in the following order: $\mathrm{C}_{2}>\mathrm{C}_{4}>\mathrm{C}_{1}=\mathrm{C}_{5}>\mathrm{C}_{3}$.

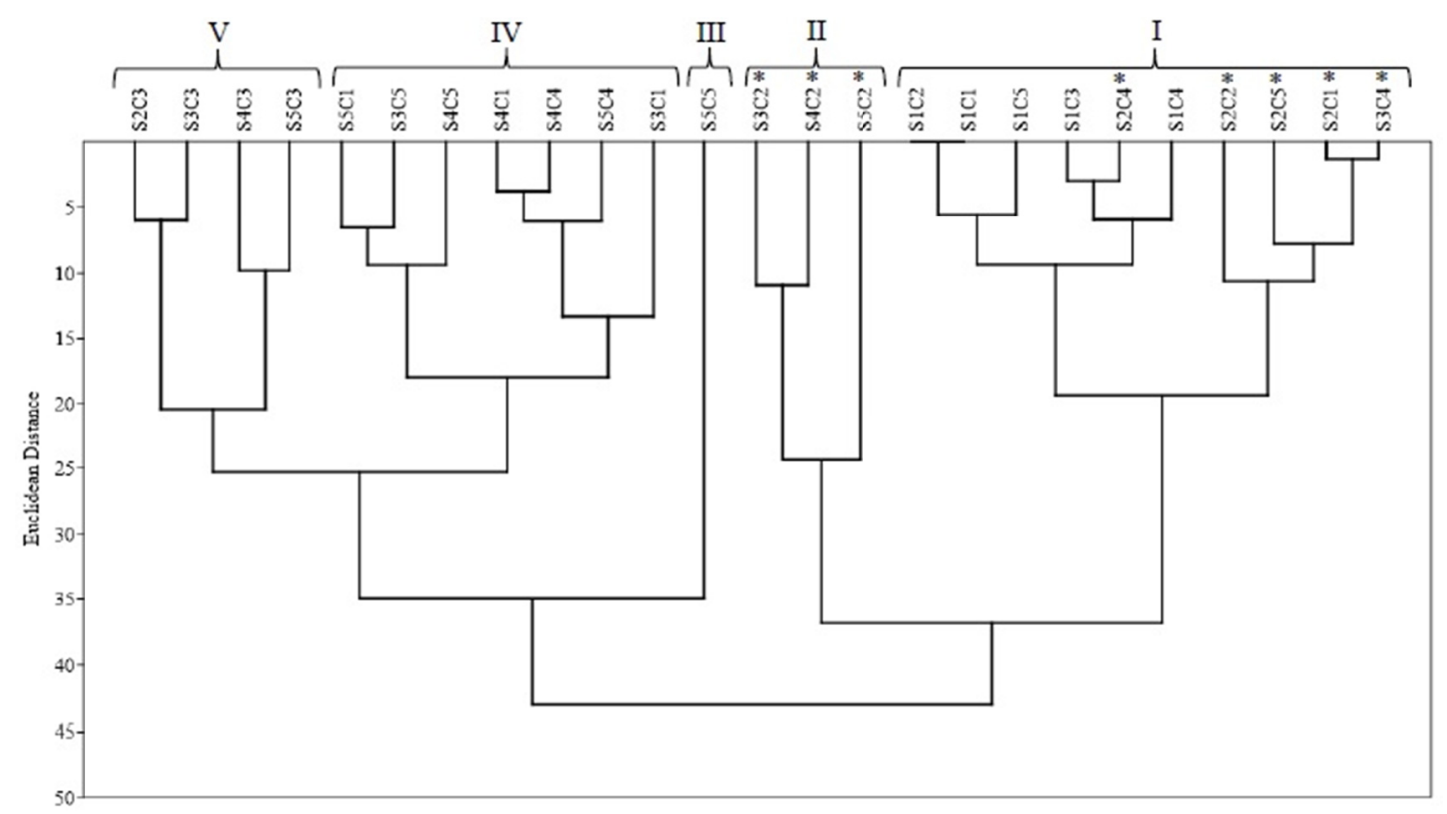

Figure 4. Dendrogram of dissimilarity of the groups formed by the combinations between salinity levels (S1 - 0.6; $\mathrm{S} 2$ - 1.2; $\mathrm{S} 3-1.8 ; \mathrm{S} 4-2.4$ and $\left.\mathrm{S} 5-3.0 \mathrm{dS} \mathrm{m} \mathrm{m}^{-1}\right)$ and bell pepper cultivars $\left(\mathrm{C}_{1}\right.$ - Dulce All Big; $\mathrm{C}_{2}-\mathrm{All} \mathrm{Big} ; \mathrm{C}_{3}$ Italiano Amarelo Gigante; $\mathrm{C}_{4}$ - Rubi Gigante; $\mathrm{C}_{5}$ - Casca Dura Ikeda)

\section{Conclusions}

The increase in irrigation water salinity affected emergence, growth and dry matter accumulation of bell pepper plants, and the cultivars $\mathrm{C}_{2}$ - All Big and $\mathrm{C}_{4}$ - Rubi Gigante were the most tolerant to salinity in the initial growth stage.

Salinity tolerance occurred in the following order: $\mathrm{C}_{2}-$ All Big $>\mathrm{C}_{4}-$ Rubi Gigante $>\mathrm{C}_{1}-$ Dulce All Big $=\mathrm{C}_{5}$ Casca Dura Ikeda $>\mathrm{C}_{3}$ - Italiano Amarelo Gigante.

\section{References}

Albuquerque, J. R. T., Sá, F. V. S., Oliveira, F. A., Paiva, E. P., Araújo, E. B. G., \& Souto, L. S. (2016). Crescimento inicial e tolerância de cultivares de pepino sob estresse salino. Rev. Bras. de Agric. Irrigada., 10(3), 486-495. https://doi.org/10.7127/rbai.v10n200355 
Andrade, F. H. A., Araújo, C. S. P., Batista, W. F., Queiroga Neto, J. A., Dantas, E. E. M., \& Andrade, R. (2016). Comportamento da cultura do pimentão submetido a diferentes níveis de salinidade. Biofarm: Rev. de Biol. e Farm., 12(3), 01-10.

Araújo, E. B. G., Sá, F. V. S., Oliveira, F. A., Souto, L. S., Paiva, E. P., Silva, M. K. N., ... Brito, M. E. B. (2016). Crescimento inicial e tolerância de cultivares de meloeiro à salinidade da água. Rev. Amb \& Água, 11(2), 462-471. https://doi.org/10.4136/ambi-agua.1726

Dias, N. S., \& Blanco, F. F. (2010). Efeitos dos sais no solo e na planta. In H. R. Gheyi, N. S. Dias, \& C. F. Lacerda (Eds.), Manejo da salinidade na agricultura: Estudos básicos e aplicados (p. 129). Fortaleza, CE.

Fageria, N. K., Soares Filho, W. S., \& Gheyi, H. R. (2010). Melhoramento genético vegetal e seleção de espécies tolerantes à salinidade. In H. R. Gheyi, N. S. Dias, \& C. F. Lacerda (Eds.), Manejo da salinidade na agricultura: Estudos básicos e aplicados (pp. 205-216). Fortaleza, CE.

Ferreira, D. F. (2011). Sisvar: A computer statistical analysis system. Ciênência \& Agrotecnologia, 35(6), 1039-1042. https://doi.org/10.1590/S1413-70542011000600001

Hair, J. F., Black, W. C., Babin, B. J., Anderson, R. E., \& Tatham, R. L. (2009). Análise multivariada de dados (6th ed., p. 688). Porto Alegre: Bookman.

Hespanhol, I. (2008). Um novo paradigma para a gestão de recursos hídricos. Estudos Avançados, 22(63), 131-158. https://doi.org/10.1590/S0103-40142008000200009

IBGE (Instituto Brasileiro de Geografia e Estatística). (2012). Levantamento sistemático da produção agrícola. Sidra. Retrieved March 3, 2017, from http://www.sidra.ibge.gov.br

Leonardo, M., Broetto, F., Villas-Bôas, R. L., Almeida, R. S., \& Marchese, J. A. (2007). Produção de frutos de pimentão em diferentes concentrações salinas. Irriga, 12(1), 73-82.

Lima, L. A., Oliveira, F. A., Alves, R. C., Linhares, P. S. F., Medeiros, A. M. A., \& Bezerra, F. M. S. (2015). Tolerância da berinjela à salinidade da água de irrigação. Rev. Agro@mbiente On-line, 9(1), $27-34$. https://doi.org/10.18227/1982-8470ragro.v9i1.2202

Lopes, J. C., \& Macedo, C. M. P. (2008). Germinação de sementes de couve chinesa sob influência do teor de água, substrato e estresse salino. Rev. Bras. de Sementes, 30(3), 079-085. https://doi.org/10.1590/ S0101-31222008000300011

Maas, E. V., \& Hoffman, G. J. (1977). Crop salt tolerance - current assessment. J. of Irrig. and Drain. Division, 103(IR 2), 115-134.

Marouelli, W. A., \& Silva W. L. C. (2012). Irrigação na cultura do pimentão (Circular Técnico 101, p. 20). Brasília: Embrapa.

Medeiros, J. F., Marcelo, C. C., Sarmento, D. H. A., \& Barros, A. D. (2007). Crescimento do meloeiro cultivado sob diferentes níveis de salinidade, com e sem cobertura do solo. Rev. Bras. de Eng. Agrí. Ambiental., 11(3), 248-255. https://doi.org/10.1590/S1415-43662007000300002

Mesquita, E. F., Sá, F. V. S., Bertino, A. M. P., Cavalcante, L. F., Paiva, E. P., \& Ferreira, N. M. (2015). Effect of soil conditioners on the chemical attributes of a saline-sodic soil and on the initial growth of the castor bean plant. Semima: Ciên. Agrárias., 36(4), 2527-2538. https://doi.org/10.5433/1679-0359.2015v36n4p2527

Moreira, M. A., Dantas, F. M., Santos, C. A. P., Oliveira, L. M., \& Moura, L. C. (2008). Produção de mudas de pimentão com o uso de pó de coco. Rev. da Fapese, 4(2), 19-26.

Munns, R., \& Tester, M. (2008). Mechanisms of salinity tolerance. Ann. Rev. Plant Biology, 59(6), 651-681. https://doi.org/10.1146/annurev.arplant.59.032607.092911

Nascimento, L. B., Medeiros, J. F., Alves, A. A. V., Lima, B. L. C., \& Silva, J. L. A. (2015). Desenvolvimento inicial da cultura do pimentão influenciado pela salinidade da água de irrigação em dois tipos de solos. Agrop. Cient. no Semiárido, 11(1), 37-43.

Oliveira, F. S., Sá, F. V. S., Souto, L. S., Paiva, E. P., Oliveira, F. A., Araújo, E. B. G., ... Mesquita, E. F. (2016). Seedling of development and tolerance of eggplant cultivars under saline stress. African J. of Agric. Research, 11(26), 2310-2315. https://doi.org/10.5897/AJAR2016.11245

Rhoades, J. D., Kandiah, A., \& Mashali, A. M. (1992). The use of saline waters for crop production. Irrigation and Drainage Paper 48 (p. 133). Rome: FAO. 
Rubio, L., Rosado, A., Linares-Rueda, A., Borsani, O., García-Sánchez, M. J., Valpuesta, V., ... Botella, M. A. (2004). Regulation of $\mathrm{K}^{+}$transport in tomato roots by the TSS1 locus. Implications in salt tolerance. Plant Physiology, 134(3), 452-459. https://doi.org/10.1104/pp.103.030361

Sá, F. V. S., Araújo, J. L., Novais, M. C., Silva, A. P., Pereira, F. H. F., \& Lopes, K. P. (2013). Crescimento inicial de arbóreas nativas em solo salino-sódico do nordeste brasileiro tratado com corretivos. Rev. Ceres, 60(3), 388-396. https://doi.org/10.1590/S0034-737X2013000300012

Sá, F. V. S., Lima, G. S., Santos, J. B., Gueyi, H. R., Soares, L.A.A., Cavalcante, L. F., .. Souza, L. P. (2016). Growth and physiological aspects of bell pepper (Capsicum annuum) under saline stress and exogenous application of proline. African J. of Biotec., 15(36), 1970-1976. https://doi.org/10.5897/AJB2016.15441

Santos, H. G., Jacomine, P. K. T., Anjos, L. H. C., Oliveira, V. A., \& Oliveira, J. B. (2013). Sistema Brasileiro de Classificação dos Solos (2th ed., p. 353). Rio de Janeiro, Embrapa Solos.

Savvas, D., Stamati, E., Tsirogiannis, I. L., Mantzos, N., Barouchas, P. E., Katsoulas, N., \& Kittas, C. (2007). Interactions between salinity and irrigation frequency in greenhouse pepper grown in closed-cycle hydroponic systems. Agric. Water Manag., 91(1-3), 102-111. https://doi.org/10.1016/j.agwat.2007.05.001

Silva, A. O., Klar, A. E., Silva, E. F. F., Tanaka, A. A., \& Silva Junior, J. F. (2013). Relações hídricas em cultivares de beterraba em diferentes níveis de salinidade do sol. Rev. Bras. de Eng. Agrí. e Ambi., 17(11), 1143-1151. https://doi.org/10.1590/S1415-43662013001100003

Silva, I. N., Fontes, L. O., Tavella, L. B., Oliveira, J. B., \& Oliveira, A. C. (2011). Qualidade de água na irrigação. Agrop. Cient. no Semiárido, 07(03), 01-15.

Taiz, L., \& Zeiger, E. (2013). Fisiologia vegetal (5th ed., p. 918). Porto Alegre: Artmed.

\section{Copyrights}

Copyright for this article is retained by the author(s), with first publication rights granted to the journal.

This is an open-access article distributed under the terms and conditions of the Creative Commons Attribution license (http://creativecommons.org/licenses/by/4.0/). 